\title{
Determinación de Trichoderma sp en raíz del cultivo de Chía (Salvia hispánica L)
}

Albrecht, Alicia B* Albrecht, Monica, Morinigo Karina.

Doctorado en Gestión Ambiental, Universidad Nacional de Itapúa. Encarnación, Paraguay.

E-mail:beatriz.belgica@ hotmail.com

Introducción: El Trichoderma sp es un hongo frecuentemente usado en actividades agrícolas, pues actúa como antagonista de diversas especies de hongos fitopatógenos, las asociaciones registradas entre hongos y raíces de plantas, varían según la clase del hongo y planta involucrada. En esta asociación, la planta proporciona los compuestos carbonados, procedentes de la fotosíntesis al hongo. Por otro lado, los hongos derivan en la incorporación de agua y minerales esenciales del suelo que después de pasar por los tejidos fúngicos, son incorporados a los tejidos de la planta (González \& Valenzuela 1993).El objetivo del presente trabajo fue determinar la presencia del hongo Trichoderma spen raíces de cultivos de Chía (Salvia hispánica L), dichas unidades de análisis corresponden a parcelas demostrativas situadas en dos departamentos, Itapúa y Misiones, respectivamente.

Materiales y métodos: La fase experimental fue realizada en el laboratorio de Microbiología de la Facultad de Ciencias y Tecnología de la Universidad Nacional de Itapúa. Las muestras de raíz fueron inicialmente desinfectadas en su superficie con hipoclorito de sodio al $2 \%$ por un periodo de tiempo de un minuto, posteriormente se enjuagó con agua destilada estéril, las misma fueron colocados sobre papel secante. Preparación y esterilización de medios de cultivo, el medio de cultivo utilizado fue el PDA (papa dextrosa agar) la cual se diluyó de acuerdo a la prescripción de la etiqueta. Las muestras fueron colocadas en placas de Petri con el medio de cultivo e incubadas durante 7 días a $26( \pm 2){ }^{\circ} \mathrm{C}$. Para la purificación del hongo se utilizó la técnica de punta de hifa Las características morfológicas fueron observadas mediante lupa estereoscópica y microscopio óptico las imágenes fueron confrontadas con bibliografía.

Resultados: Se reconoce la presencia de Trichodermasp en las muestras, de raíz tomada en cada localidad, siendo este un organismo dominante en suelo, debido a su naturaleza agresiva y su capacidad metabólica compite con la densa microflora de ambos departamentos analizados. Las cepas germinan y desarrollan un micelio capaz de enfrentar patógenos. En la figura 1 se puede observar las características del crecimiento del hongo.

Conclusiones: Concibiendo el parasitismo directo del género descripto, se resalta el potencial de secreción de enzimas de la cepa, estas son capaces de disolver la pared celular de las hifas huésped, como también se reconoce la capacidad de absorción de nutrientes desde el interior, quedando el micelio parasitado vacío y perforado.Debe asumirse que el parasitismo constituye un método de acción, siendo la generación de antibióticos otro método, capaz de inhibir el desarrollo de ciertos patógenos, como ser hongos y bacterias.

Agradecimientos: A la Facultad de Ciencias y Tecnologías de la Universidad Nacional de Itapúa por permitir el uso de sus instalaciones para llevar a cabo la investigación. A

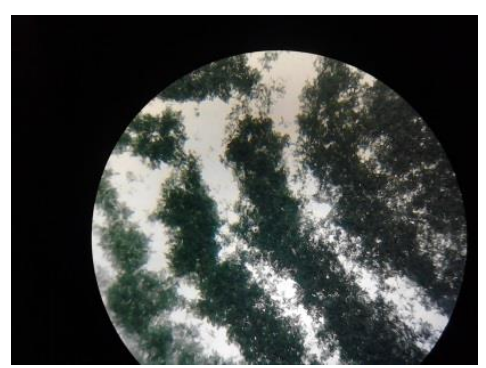

B

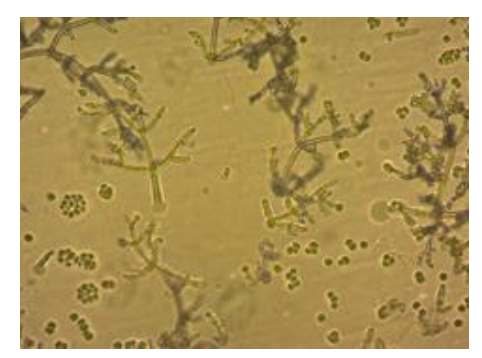

$\mathrm{C}$

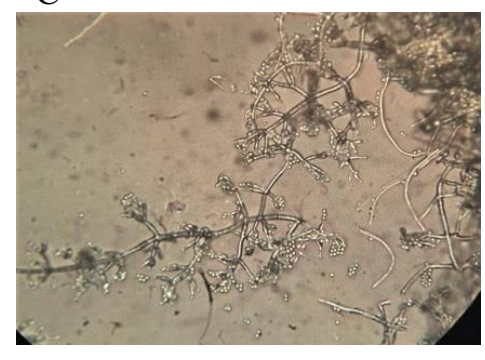

Figura 1: Crecimiento de Trichoderma $s p$ Vista Estereoscópica A; Vista microscópica B, C (Albrecht 2017) 